\title{
Mengidentifikasi Sistem Operasi
}

\author{
Abriani Dewi Oktavia \\ 195120003 \\ Fakultas Komputer \\ Abrianidewioktavia.student@umitra.ac.id
}

\section{Isi Resume :}

Suatu proses adalah lebih dari kode program. Proses termasuk aktivitas yang sedang terjadi, sebagaimana digambarkan oleh nilai pada program counter dan isi dari daftar prosesor/ processor's register. Suatu proses umumnya termasuk process stack, yang berisikan data temporer (seperti parameter metoda, address yang kembali, dan variabel lokal) dan sebuah data section, yang berisikanvariabel global.

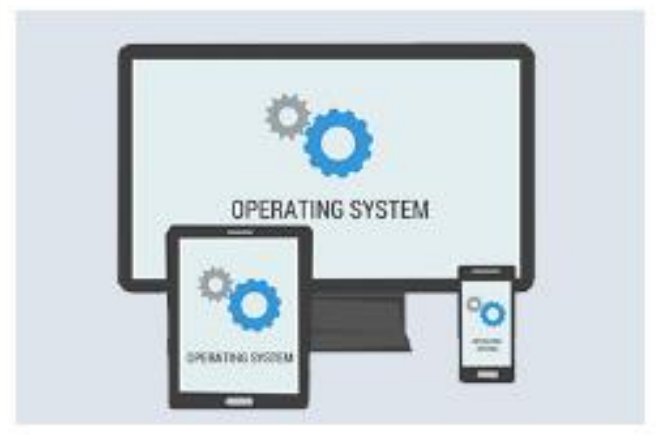

Sebagaimana proses bekerja, maka proses tersebut merubah state (keadaan statis/ asal). Status dari sebuah proses didefinisikan dalam bagian oleh aktivitas yang ada dari proses tersebut. Tiap proses mungkin adalah satu dari keadaan berikut ini:

- New: Proses sedang dikerjakan/ dibuat.

- Running: Instruksi sedang dikerjakan.

- Waiting: Proses sedang menunggu sejumlah kejadian untuk terjadi (seperti sebuah penyelesaian I/Oatau penerimaan sebuah tanda/ signal).

- Ready: Proses sedang menunggu untuk ditugaskan pada sebuah prosesor.

- Terminated: Proses telah selsesai melaksanakan tugasnya/ mengeksekusi.

Nama-nama tersebut adalah arbitrer/ berdasar opini, istilah tersebut bervariasi disepanjang sistem operasi. Keadaan yang mereka gambarkan ditemukan pada seluruh sistem. Namun, sistem operasi tertentu juga lebih baik menggambarkan keadaan/ status proses. Adalah penting untuk menyadari bahwa hanya satu proses dapat berjalan pada prosesor mana pun pada waktu kapan pun. Namun, banyak proses yang dapat ready atau waiting. Keadaan diagram yang berkaitan dangan keadaan tersebut dijelaskan pada Gambar 1. 


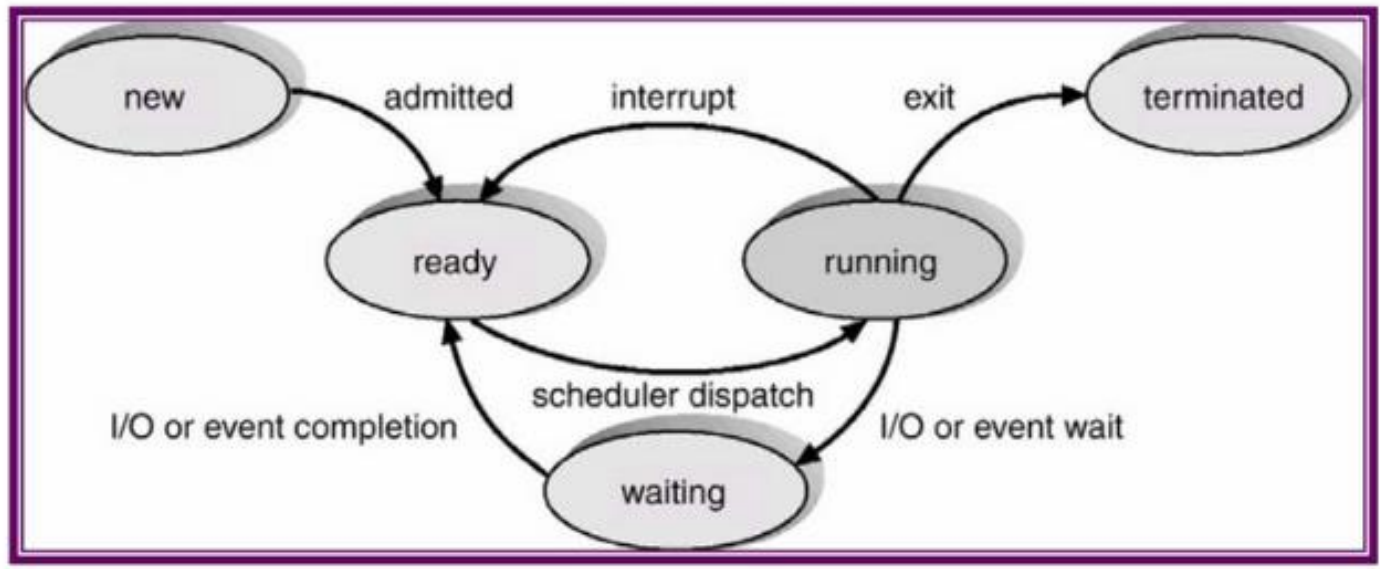

Suatu proses dapat membuat beberapa proses baru, melalui sistem pemanggilan pembuatan proses, selama jalur eksekusi. Pembuatan proses dinamakan induk proses, sebagaimana proses baru disebut anak dari proses tersbut. Tiap proses baru tersebut dapat membuat proses lainnya, membentuk suatu pohon proses.

Secara umum, suatu proses akan memerlukan sumber tertentu (waktu CPU, memori, berkas, perangkat I/O) untuk menyelesaikan tugasnya. Ketika suatu proses membuat sebuah subproses, sehingga subproses dapat mampu untuk memperoleh sumbernya secara langsung dari sistem operasi. Induk mungkin harus membatasi sumber diantara anaknya, atau induk dapat berbagi sebagian sumber (seperti memori berkas) diantara beberapa dari anaknya. Membatasi suatu anak proses menjadi subset sumber daya induknya mencegah proses apa pun dari pengisian sistem yang telalu banyak dengan menciptakan terlalu banyak subproses.

Ketika suatu proses membuat proses baru, dua kemungkinan ada dalam term eksekusi:

1. Induk terus menerus untuk mengeksekusi secara bersama-sama dengan anaknya.

2. Induk menunggu sampai sebagian dari anaknya telah diakhiri/terminasi.

Juga ada dua kemungkinan dalam term dari address space pada proses baru: 1. Anak proses adalah duplikat dari induk proses.

2. Anak proses memiliki program yang terisikan didalamnya.

Untuk mengilustrasikan implementasi yang berbeda ini, mari kita mempelajari sistem operasi UNIX. Dalam UNIX, tiap proses diidentifikasi oleh pengidentifikasi proses, yang merupakan integer yang unik. Proses baru dibuat oleh sistem pemanggilan fork 
system call. Proses baru tersebut terdiri dari sebuah copy ruang alamat dari proses aslinya (original). Mekanisme tersebut memungkinkan induk proses untuk berkomunikasi dengan mudah dengan anak proses. Kedua proses (induk dan anak) meneruskan eksekusi pada instruksi setelah fork dengan satu perbedaan: Kode kembali untuk fork adalah nol untuk proses baru (anak), sebagaimana proses pengidentifikasi non nol (non zero) dari anak dikembalikan kepada induk.

Umumnya, sistem pemanggilan execlp digunakan setelah sistem pemanggilan fork. Oleh satu dari dua proses untuk menggantikan proses ruang memori dengan program baru. Sistem pemanggilan execlp mengisi suatu berkas binary kedalam memori (menghancurkan gambar memori pada program yang berisikan sistem pemanggilan execlp) dan memulai eksekusinya. Dengan cara ini, kedua proses mampu untuk berkomunikasi, dan lalu untuk pergi ke arah yang berbeda. Induk lalu dapat membuat anak yang lebh banyak atau jika induk tidak punya hal lain untuk dilakukan ketika anak bekerja, induk dapat mengeluarkan sistem pemanggilan wait untuk tidak menggerakkan dirinya sendiri pada suatu antrian yang siap sampai anak berhenti. Program C ditunjukkan pada Gambar 2-10 mengilustrasikan sistem pemanggilan pada UNIX yang sebelumnya dijelaskan. Induk membuat anak proses menggunakan sistem pemanggilan fork(). Kini kita mempunyai dua proses yang berbeda yang menjalankan sebuah copy pada program yang sama. Nilai dari pid untuk anak proses adalah nol (zero): maka untuk induk adalah nilai integer yang lebih besar dari nol. Anak proses meletakkan ruang alamatnya dengan UNIX command/bin/ls (digunakan untuk mendapatkan pendaftaran directory) menggunakan sistem pemanggilan execlp(). Ketika anak proses selesai, induk proses menyimpulkan dari pemanggilan untuk wait() dimana induk proses menyelesaikannya dengan menggunakan sistem pemanggilan exit().

Secara kontras, sistem operasi DEC VMS membuat sebuah proses baru dengan mengisi program tertentu kedalam proses tersebut, dan memulai pekerjaannya. Sistem operasi Microsoft Windows NT mendukung kedua model: Ruang alamat induk proses dapat di duplikasi, atau induk dapat menspesifikasi nama dari sebuah program untuk sistem operasi untuk diisikan kedalam ruang alamat pada proses baru.

Terminasi Proses

Sebuah proses berakhir ketika proses tersebut selesai mengeksekusi pernyataan akhirnya dan meminta sistem operasi untuk menghapusnya dengan menggunakan sistem pemanggilan exit. Pada titik itu, proses tersebut dapat mengembalikan data (keluaran) pada induk prosesnya (melalui sistem pemanggilan wait). Seluruh sumbersumber dari proses-termasuk memori fisik dan virtual, membuka berkas, dan penyimpanan I/O di tempatkan kembali oleh sistem operasi.

Ada situasi tambahan tertentu ketika terminasi terjadi. Sebuah proses dapat menyebabkan terminasi dari proses lain melalui sistem pemanggilan yang tepat (contoh abort). Biasanya, sistem seperti itu dapat dipanggil hanya oleh induk proses 
tersebut yang akan diterminasi. Bila tidak, pengguna dapat secara sewenang-wenang membunuh job antara satu sama lain. Catat bahwa induk perlu tahu identitas dari anaknya. Maka, ketika satu proses membuat proses baru, identitas dari proses yang baru diberikan kepada induknya.

Induk dapat menterminasi/ mengakhiri satu dari anaknya untuk beberapa alasan, seperti:

- Anak telah melampaui kegunaannya atas sebagaian sumber yang telah diperuntukkan untuknya.

- Pekerjaan yang ditugaskan kepada anak telah keluar, dan sistem operasi tidak memeperbolehkan sebuah anak untuk meneruskan jika induknya berakhir. Untuk menentukan kasus pertama, induk harus memiliki mekanisme untuk memeriksa status anaknya. Banyak sistem, termasuk VMS, tidak memperbolehkan sebuah anak untuk ada jika induknya telah berakhir. Dalam sistem seperti ini, jika suatu proses berakhir (walau secara normal atau tidak normal), maka seluruh anaknya juga harus diterminasi. Fenomena ini, mengacu pada terminasi secara cascading, yang normalnya dimulai oleh sistem operasi.

Untuk mengilustrasikan proses eksekusi dan proses terminasi, kita menganggap bahwa, dalam UNIX, kami dapat mengakhiri suatu proses dengan sistem pemanggilan exit; proses induknya dapat menunggu untuk terminasi anak proses dengan menggunakan sistem pemanggilan wait. Sistem pemanggilan wait kembali ke pengidentifikasi proses dari anak yang telah diterminasi, maka induk dapat memberitahu kemungkinanan anak mana yang telah diterminasi. Jika induk menterminasi. Maka, anaknya masih punya sebuah induk untuk mengumpulkan status mereka dan mengumpulkan statistik eksekusinya.

\section{Hubungan Antara Proses}

Sebelumnya kita telah ketahui seluk beluk dari suatu proses mulai dari pengertiannya, cara kerjanya, sampai operasi-operasinya seperti proses pembentukannya dan proses pemberhentiannya setelah selesai melakukan eksekusi. Kali ini kita akan mengulas bagaimana hubungan antar proses dapat berlangsung, misal bagaimana beberapa proses dapat saling berkomunikasi dan bekerja-sama.

Proses yang Kooperatif

Proses yang bersifat simultan (concurrent) dijalankan pada sistem operasi dapat dibedakaan menjadi yaitu proses independent dan proses kooperatif. Suatu proses dikatakan independen apabila proses tersebut tidak dapat terpengaruh atau dipengaruhi oleh proses lain yang sedang dijalankan pada sistem. Berarti, semua proses yang tidak membagi data apa pun (baik sementara/ tetap) dengan proses lain adalah independent. Sedangkan proses kooperatif adalah proses yang dapat dipengaruhi atau pun terpengaruhi oleh proses lain yang sedang dijalankan dalam sistem. Dengan kata lain, proses dikatakan kooperatif bila proses 
dapat membagi datanya dengan proses lain. Ada empat alasan untuk penyediaan sebuah lingkungan yang memperbolehkan terjadinya proses kooperatif:

1. Pembagian informasi: apabila beberapa pengguna dapat tertarik pada bagian informasi yang sama (sebagai contoh, sebuah berkas bersama), kita harus menyediakan sebuah lingkungan yang mengizinkan akses secara terus menerus ke tipe dari sumber-sumber tersebut.

2. Kecepatan penghitungan/ komputasi: jika kita menginginkan sebuah tugas khusus untuk menjalankan lebih cepat, kita harus membagi hal tersebut ke dalam subtask, setiap bagian dari subtask akan dijalankan secara parallel dengan yang lainnya. Peningkatan kecepatan dapat dilakukan hanya jika komputer tersebut memiliki elemen-elemen pemrosesan ganda (seperti CPU atau jalur I/O).

3. Modularitas: kita mungkin ingin untuk membangun sebuah sistem pada sebuah model modular-modular, membagi fungsi sistem menjadi beberapa proses atau threads.

4. Kenyamanan: bahkan seorang pengguna individu mungkin memiliki banyak tugas untuk dikerjakan secara bersamaan pada satu waktu. Sebagai contoh, seorang pengguna dapat mengedit, memcetak, dan meng-compile secara paralel.

Komunikasi Proses Dalam Sistem

Cara lain untuk meningkatkan efek yang sama adalah untuk sistem operasi yaitu untuk menyediakan alat-alat proses kooperatif untuk berkomunikasi dengan yang lain lewat sebuah komunikasi dalam proses (IPC $=$ Inter-Process Communication). IPC menyediakan sebuah mekanisme untuk mengizinkan proses-proses untuk berkomunikasi dan menyelaraskan aksi-aksi mereka tanpa berbagi ruang alamat yang sama. IPC adalah khusus digunakan dalam sebuah lingkungan yang terdistribusi dimana proses komunikasi tersebut mungkin saja tetap ada dalam komputerkomputer yang berbeda yang tersambung dalam sebuah jaringan. IPC adalah penyedia layanan terbaik dengan menggnakan sebuah sistem penyampaian pesan, dan sistem-sistem pesan dapat diberikan dalam banyak cara.

Sistem Penyampaian Pesan

Fungsi dari sebuah sistem pesan adalah untuk memperbolehkan komunikasi satu dengan yang lain tanpa perlu menggunakan pembagian data. Sebuah fasilitas IPC menyediakan paling sedikit dua operasi yaitu kirim (pesan) dan terima (pesan). Pesan dikirim dengan sebuah proses yang dapat dilakukan pada ukuran pasti atau variabel. Jika hanya pesan dengan ukuran pasti dapat dikirimkan, level sistem implementasi adalah sistem yang sederhana. Pesan berukuran variabel menyediakan sistem implementasi level yang lebih kompleks. 

$\sum^{*^{* *}} \begin{aligned} & \text { Fakultas Komputer } \\ & \text { Resume Upload OSF }\end{aligned}$

Abriani Dewi Oktavia 


\section{A. ID SECURITY \\ QWTD44112377-ASP-524414475}

\section{B. REFERENCE}

[1] O. M. Febriani and A. S. Putra, "Sistem Informasi Monitoring Inventori Barang Pada Balai Riset Standardisasi Industri Bandar Lampung," J. Inform., vol. 13, no. 1, pp. 90-98, 2014.

[2] A. S. Putra, "Paperplain: Execution Fundamental Create Application With Borland Delphi 7.0 University Of Mitra Indonesia," 2018.

[3] A. S. Putra, "2018 Artikel Struktur Data, Audit Dan Jaringan Komputer," 2018.

[4] A. S. Putra, "ALIAS MANAGER USED IN DATABASE DESKTOP STUDI CASE DB DEMOS."

[5] A. S. Putra, "COMPREHENSIVE SET OF PROFESSIONAL FOR DISTRIBUTE COMPUTING."

[6] A. S. Putra, "DATA ORIENTED RECOGNITION IN BORLAND DELPHI 7.0."

[7] A. S. Putra, "EMBARCADERO DELPHI XE 2 IN GPU-POWERED FIREMONKEY APPLICATION."

[8] A. S. Putra, "HAK ATAS KEKAYAAN INTELEKTUAL DALAM DUNIA TEKNOLOGY BERBASIS REVOLUSI INDUSTRI 4.0."

[9] A. S. Putra, "IMPLEMENTASI PERATURAN PERUNDANGAN UU. NO 31 TAHUN 2000 TENTANG DESAIN INDUSTRI BERBASIS INFORMATION TECHNOLOGY."

[10] A. S. Putra, "IMPLEMENTATION OF PARADOX DBASE."

[11] A. S. Putra, "IMPLEMENTATION OF TRADE SECRET CASE STUDY SAMSUNG MOBILE PHONE."

[12] A. S. Putra, "IMPLEMENTATION PATENT FOR APPLICATION WEB BASED CASE STUDI WWW. PUBLIKLAMPUNG. COM."

[13] A. S. Putra, "IMPLEMENTATION SYSTEM FIRST TO INVENT IN DIGITALLY INDUSTRY."

[14] A. S. Putra, "MANUAL REPORT \& INTEGRATED DEVELOPMENT ENVIRONMENT BORLAND DELPHI 7.0."

[15] A. S. Putra, "PATENT AS RELEVAN SUPPORT RESEARCH."

[16] A. S. Putra, "PATENT FOR RESEARCH STUDY CASE OF APPLE. Inc."

[17] A. S. Putra, "PATENT PROTECTION FOR APPLICATION INVENT."

[18] A. S. Putra, "QUICK REPORT IN PROPERTY PROGRAMMING."

[19] A. S. Putra, "REVIEW CIRCUIT LAYOUT COMPONENT REQUIREMENT ON ASUS NOTEBOOK."

[20] A. S. Putra, "REVIEW TRADEMARK PATENT FOR INDUSTRIAL TECHNOLOGY BASED 4.0."

[21] A. S. Putra, "TOOLBAR COMPONENT PALLETTE IN OBJECT ORIENTED PROGRAMMING." 
[22] A. S. Putra, "WORKING DIRECTORY SET FOR PARADOX 7."

[23] A. S. Putra, "ZQUERY CONNECTION IMPLEMENTED PROGRAMMING STUDI CASE PT. BANK BCA Tbk."

[24] A. S. Putra, D. R. Aryanti, and I. Hartati, "Metode SAW (Simple Additive Weighting) sebagai Sistem Pendukung Keputusan Guru Berprestasi (Studi Kasus: SMK Global Surya)," in Prosiding Seminar Nasional Darmajaya, 2018, vol. 1, no. 1, pp. 85-97.

[25] A. S. Putra and O. M. Febriani, "Knowledge Management Online Application in PDAM Lampung Province," in Prosiding International conference on Information Technology and Business (ICITB), 2018, pp. 181-187.

[26] A. S. Putra, O. M. Febriani, and B. Bachry, "Implementasi Genetic Fuzzy System Untuk Mengidentifikasi Hasil Curian Kendaraan Bermotor Di Polda Lampung," SIMADA (Jurnal Sist. Inf. dan Manaj. Basis Data), vol. 1, no. 1, pp. 21-30, 2018.

[27] A. S. Putra, H. Sukri, and K. Zuhri, "Sistem Monitoring Realtime Jaringan Irigasi Desa (JIDES) Dengan Konsep Jaringan Sensor Nirkabel," IJEIS (Indonesian J. Electron. Instrum. Syst., vol. 8, no. 2, pp. 221-232.

[28] D. P. Sari, O. M. Febriani, and A. S. Putra, "Perancangan Sistem Informasi SDM Berprestasi pada SD Global Surya," in Prosiding Seminar Nasional Darmajaya, 2018, vol. 1, no. 1, pp. 289-294. 